\title{
THE EFFECT OF WATER SALINITY ON THE MOTILITY OF SPERMATOZOA OF THE BROOK TROUT, SALVELINUS FONTINALIS (ACTINOPTERYGII: SALMONIFORMES: SALMONIDAE)
}

\author{
Małgorzata BONISŁAWSKA ${ }^{1 *}$, Joanna SZULC ${ }^{2}$, and Krzysztof FORMICKI ${ }^{2}$ \\ ${ }^{1}$ Division of Aquatic Sozology; \\ ${ }^{2}$ Division of Hydrobiology, Ichthyology and Biotechnology of Reproduction; West Pomeranian University \\ of Technology in Szczecin, Szczecin, Poland
}

Bonisławska M., Szulc J., Formicki K. 2015. The effect of water salinity on the motility of spermatozoa of the brook trout, Salvelinus fontinalis (Actinopterygii: Salmoniformes: Salmonidae). Acta Ichthyol. Piscat. 45 (2): 143-151.

\begin{abstract}
Background. Salmonid spermatozoa are characterised by a very short time of activity in the water, therefore sudden water pollution in the form of increased salinity on the spawning grounds may have a negative effect on the sperm motility parameters, thus affecting the subsequent egg fertilisation and, consequently, the number of hatched individuals of the species. The aim of this study was to determine the effect of water salinity on the motility parameters of spermatozoa of brook trout, Salvelinus fontinalis (Mitchill, 1814).

Material and methods. Sperm motility was monitored with a camera (Basler A312fc) coupled with Nikon Eclipse $50 \mathrm{i}$ light microscope from the moment of their activation (contact with water) until the cessation of movement. The following water-salinity treatments were tested: $1.0 \%$, 3.0\%, 5.0\%o, and 10.0\%. The motility parameters: VCL, VSL, VAP, ALH, BCF, LIN, STR, WOB, and MOT, were analysed with Computer Assisted Sperm Analysis (CASA). Results. The mean values of the studied motility parameters of the brook trout spermatozoa (obtained within $30 \mathrm{~s}$ ), whose activation took place in the water of $0.35 \%$ salinity and in water of $1.0 \%$ and $3.0 \%$ salinity, did not differ significantly. The highest mean values of motility parameters were recorded for the water of 5.0\%o salinity. The $10.0 \%$ treatment caused a distinct decrease in the values of all the studied parameters. The percentage of MOT was the highest $(37.5 \%)$ in the sample activated in the water used for fish rearing $(0.35 \%)$. In the remaining samples the MOT was lower, and in the water of $10.0 \%$ salinity it was only $9.1 \%$. No spermatozoa movement of any kind was recorded in the 35 th second of the experiment.

Conclusion. The values of the motility parameters as well as the percentage of motile spermatozoa (MOT) in the semen decrease with increasing salinity of the water used for activation, and with increasing time of exposure.
\end{abstract}

Keywords: sperm quality, CASA, salinity, brook trout, Salvelinus fontinalis

\section{INTRODUCTION}

Different water salinity may have an effect on aquatic organisms, including fishes. It may affect fish gametes (eggs and spermatozoa), developing embryos, as well as juveniles and adults (Swanson 1996, Vetemaa and Saat 1996, Fashina-Bombata and Busari 2003, Bonisławska 2009, Fridman et al. 2012, Khatooni et al. 2012).

Studies on the effect of water salinity on spermatozoa of freshwater fishes have a fairly long history (Ivlev 1940, Lindroth 1946, Dziekońska 1958, Szymelfenig 1979, Landergren and Vallin 1998, Beirão et al. 2015a, $2015 b)$. It has been found that the activity of fish spermatozoa decreases with increasing salinity, and their ability to fertilise eggs decreases accordingly. Spermatozoa of freshwater bream, Abramis brama (Linnaeus, 1758) from the Caspian Sea remained motile in the salinity water of
$11.0 \%$, but they were incapable of fertilisation (Ivlev 1940). In the same species from the Vistula Lagoon the spermatozoa were motile at 5.6\% salinity, but the value of $11.0 \%$ was too high and no movement was recorded in such samples (Dziekońska 1958). The spermatozoa motility of pike, Esox lucius Linnaeus, 1758 at $4.0 \%{ }^{-}-7.0 \%$ was the same as in lake water, while at $30.0 \%$ o they were immobile (Lindroth 1946).

Studies on the possibility of reproduction of two salmonid species - the rainbow trout, Oncorhynchus mykiss (Walbaum, 1792), and brown trout, Salmo trutta Linnaeus, 1758 - in the water from the Baltic Sea, showed that water salinity within $4.0 \%-7.4 \%$ prolonged the time of sperm motility, compared to that in freshwater. The spermatozoa of rainbow trout and brown trout moved also in the water of higher salinity, up to $15.0 \%$ (Szymelfenig 1979). 
Twenty years later, studies by Landergren and Vallin (1998) showed that brown trout spermatozoa displayed their highest motility in freshwater and in the brackish water of $6.7 \%$ o from the coast of Gotland Island (Baltic Sea). Higher salinity (10.0\%o and $14.0 \%$ ) caused a decrease in motility, and at the level of $16.0 \%$ and $18.0 \%$ o the movement ceased. Motility was also observed that at $6.7 \%$, despite the normal fertilisation, the brown trout embryogenesis was inhibited and no hatching occurred (Landergren and Vallin 1998). The results of Bonisławska (2009) indicated the salinity value of $2.0 \%$ as the upper limit for normal completion of embryogenesis and hatching. At 3.0\%, despite the $83 \%$ of fertilised eggs, there was a mass mortality of embryos before hatching (Bonisławska 2009).

Comparison of sperm motility in two species: marine capelin, Mallotus villosus (Müller, 1776), and the anadromous rainbow smelt, Osmerus mordax (Mitchill, 1814) in water salinities from $0.0 \%$ to $30.0 \%$ showed the greatest motility of capelin spermatozoa at 5.0\%o, 10.0\%o, and $15.0 \%$ (MOT $75 \%-80 \%$ ). In the case of rainbow smelt the greatest MOT values were obtained at $0.0 \%$, 5.0\%o, and $10.0 \%$ water salinity (MOT $75 \%-85 \%$ ). At $15.0 \%$ and $20.0 \%$, the MOT of rainbow smelt spermatozoa was $15.0 \%-20.0 \%$, and at $30.0 \%$ no movement was observed (Beirão et al. 2013).

The proportion of motile spermatozoa in fish semen determines its quality, which is crucial for fertilisation (Billard 1978, Stoss 1983). Spermatozoa of the majority of fish species are immobile in the seminal plasma and acquire motility only during activation (contact with water). Sperm motility is initiated by the difference in the concentration of potassium ions $\mathrm{K}^{+}$between the seminal plasma and the water (salmonids) or by a decrease in osmotic pressure (freshwater teleosts) (Billard 1986, Gatti et al. 1990). The movement of sperm tail requires great amounts of energy, acquired from ATP hydrolysis. The energy (ATP) shortly becomes exhausted, hence the short time of fish sperm motility; the time varies among species (Cosson et al. 1999, Burness et al. 2005). Assessment of sperm motility is necessary, since fertilising capacity depends strictly on motility (Gage et al. 2004). Also important is the fact that sperm motility is influenced by a variety of environmental factors such as temperature, concentration of univalent and bivalent ions in the water (salmonids and acipenserids), osmolality (cyprinids and marine fishes), pH, and magnetic field (Scheuring 1925, Morisawa et al. 1983, Cosson et al. 1999, Inaba et al. 2003, Krasznai et al. 2003, Alavi and Cosson 2005, 2006, Shimoda et al. 2007, Alavi et al. 2008, Ciereszko 2008, Formicki et al. 2013).

Consequently, re-occurring appearance of anthropogenic substances in lakes and rivers may, through the change of water parameters ( $\mathrm{pH}$, temperature, or concentration of ions), affect the motility parameters of fish spermatozoa. A very important factor is the increasing salinity of inland waters of Poland, resulting from various kinds of pollution. The main sources of water salinity include mining $(79.0 \%)$, chemical industry $(12.0 \%)$, area pollution $(7.0 \%)$, metallurgic industry $(1.5 \%)$, and thermal power plant effluents (0.5\%) (Szymańska 1990). Pollution of the two largest rivers in Poland-Vistula and Oder, in the form of increased salinity (increased concentration of chlorides and sulphates) is a result of coal-mine draining in Upper Silesia (Janson et al. 2009). In the autumn-winter period the salinity of lakes, rivers, and streams often increases as a result of common usage of salt for winter maintenance of roads. The autumn-winter as well as early spring periods are the times of spawning of economically important and pollution-sensitive salmonids (Salmonidae), including brook trout, Salvelinus fontinalis (Mitchill, 1814). This species, like all other representatives of the family, inhabits pure and cold rivers and streams of stony bottom. It was introduced in Europe in the 19th century, and in Poland - in the 1960s (Fopp-Bayat et al. 2010). Individuals found in European rivers may represent intentional stocking or fish-farm escapes.

A thorough literature search shows a lack of studies performed with the use of Computer Assisted Sperm Analysis (CASA) and dealing with the effect of pollution in the form of increased water salinity on the motility parameters of spermatozoa of fishes, including brook trout.

The objective of this study was to determine the effect of increased water salinity $\left(1.0 \%{ }^{-}-10.0 \%\right)$ on the motility parameters of brook trout spermatozoa from the moment of their contact with water until the cessation of movement. We hoped to answer the question if and to what extent re-occurring pollution in the form of increased water mineralization affects fertilisation through direct effect on the sperm motility parameters. Our study may help to explain the effect of external factors on the decrease in the number of hatched individuals of various fish species in the rivers of Poland.

\section{MATERIAL AND METHODS}

Semen was sampled from brook trout males from a fish farm near the town of Miastko in north-western Poland $\left(54^{\circ} 01^{\prime} \mathrm{N}, 16^{\circ} 59^{\prime} \mathrm{E}\right)$ in the second half of October 2013 (water temperature $7.0^{\circ} \mathrm{C}$ ).

The semen was obtained from 13 males (no anaesthetics were used) at the peak of the spawning season. Their total length (TL) was $25-38 \pm 0.5 \mathrm{~cm}$ and body mass 280 $350 \pm 0.5 \mathrm{~g}$.

The semen was sampled from each male separately, using a syringe with silicone catheter; care being taken not to contaminate the sample with faeces, urine, or blood. The semen (not diluted) was transported to the laboratory in test tubes placed in isothermal containers with cooling lining which ensured the adequate, constant temperature of $7.0 \pm 0.1^{\circ} \mathrm{C}$ during the transport. The duration of the transport was $90 \mathrm{~min}$.

Sperm motility. The sperm motility parameters were assessed using Computer Assisted Sperm Analysis (CASA) with computer system for sperm motility analysis (SCA)-Sperm Class Analyzer v. 4.0.0. (Microptic S.L.) software. Sperm motility was monitored with a camera (Basler A312fc) coupled with Nikon Eclipse 50i light microscope $(\times 10$ negative phase contrast objective). 
The amount of $5 \mu \mathrm{L}$ of semen and activating liquid mixture $(1: 250)$ was placed in the Makler chamber (Sefi - Medical Instruments, Israel) and the analysis started after ca. $3 \mathrm{~s}$. The chamber, made with a laser technique, is $10 \mu \mathrm{m}$ deep, which enables the spermatozoa to move freely but prevents them from making vertical movement and thus disappearing from the field of vision. The motility was recorded at 5-s intervals until the cessation of movement. Each sample was analysed in triplicate.

The following sperm motility parameters CASA System were assessed:

- Curvilinear velocity (VCL) $\left[\mu \mathrm{m} \cdot \mathrm{s}^{-1}\right]$;

- Straight-line velocity (VSL) $\left[\mu \mathrm{m} \cdot \mathrm{s}^{-1}\right]$;

- Average-pathsperm velocity (VAP) $\left[\mu \mathrm{m} \cdot \mathrm{s}^{-1}\right]$;

- Amplitude of lateral head displacement (ALH) $[\mu \mathrm{m}]$;

- Beat cross frequency $(\mathrm{BCF})[\mathrm{Hz}]$;

- Linear motion (LIN) $[\%]\left(100 \mathrm{VSL} \cdot \mathrm{VCL}^{-1}\right)$;

- Motion straightness (STR) [\%] (100VSL $\left.\cdot \mathrm{VAP}^{-1}\right)$;

- Minimum and maximum value of sperm oscillation in$\operatorname{dex}(\mathrm{WOB})[\%]$;

- Proportion of motile spermatozoa (MOT) (motility).

Experimental design and hydrochemical analysis

In order to activate the spermatozoa, the semen was mixed with water activators, constituting five experimental treatments differing in salinity: $0.35 \%, 1.0 \%$, 3.0\%o, 5.0\%o, and $10.0 \%$. The salinity of $0.35 \%$ represented water from the fish culture. The aqueous salt solutions used were based on sea salt (hw Marinemix Meersalz Professional, hw Wiegandt, Krefeld, Germany) and deionised water (ultra-pure). Magnetic stirrer (MS HS, Vigo, Spain) was used when preparing the solutions. Analyses of the water from the fish culture and of the salt solutions were performed at the Division of Hydrochemistry and Water Protection of our university, using ion exchange chromatograph Dione ICS 3000 (Table 1).

Statistical analyses. The results were statistically analysed with Statistica v.10 PL software (StatSoft) using univariate variance analysis (ANOVA, $P<0.01$ ) and Duncan test $(P<0.01)$ to compare the mean values of the motility parameters.

\section{RESULTS}

The values of the studied motility parameters and the proportion of motile spermatozoa in the semen decreased with increasing salinity of the water and with the time of exposure. In all the samples no movement was observed in the 35 th second.

Curvilinear velocity (VCL) of brook trout spermatozoa during the first seconds following contact with the culture water and the water of $1.0 \%$ salinity was the highest (at a similar level), of 92.49 and $87.39 \mu \mathrm{m} \cdot \mathrm{s}^{-1}$, respectively. VCL decreased with time elapsing from the moment of activation, and the differences became increasingly pronounced. In the 30th second the VCL of spermatozoa in the culture water was $19.38 \mu \mathrm{m} \cdot \mathrm{s}^{-1}$, and in the water of $1.0 \%-14.74 \mu \mathrm{m} \cdot \mathrm{s}^{-1}$. In case of solutions of $3.0 \%$ and $10.0 \%$ the VCL also decreased, and in the water of $5.0 \%$ in the 5th second from activation the VCL increased to reach its maximum of $96.0 \mu \mathrm{m} \cdot \mathrm{s}^{-1}$, while in the $30 \mathrm{th} \mathrm{sec}-$ ond its value was only $16.20 \mu \mathrm{m} \cdot \mathrm{s}^{-1}$. The lowest VCL value both at the beginning and 30 seconds after activation was recorded for the spermatozoa in the water of $10.0 \%$ : in the first seconds it was $22.12 \mu \mathrm{m} \cdot \mathrm{s}^{-1}$, and in the 30th second only $12.93 \mu \mathrm{m} \cdot \mathrm{s}^{-1}$ (Fig. 1a).

The statistical analysis of the mean VCL of spermatozoa during activation (during 30 seconds) showed significant differences between the mean VCL in the water of $0.35 \%, 1.0 \%$, and $3.0 \%$ on the one hand and the VCL in the water of $5.0 \%$ and $10.0 \%$ on the other (Table 2).

Straight-line velocity (VSL) of the brook trout spermatozoa also decreased with time, but in this case the highest VSL values were reached in the 5th and 10th second of activation at the water of $5.0 \% 0-74.3$ and $43.4 \mu \mathrm{m} \cdot \mathrm{s}^{-1}$, respectively (Fig. 1b). In the culture water, on the beginning of activation, VSL was lower compared to spermatozoa activated in the water of $1.0 \%$ and $5.0 \%$. The highest VSL value in the 30th second of activation was recorded for the spermatozoa activated in the culture water. The lowest VCL values were observed for the spermatozoa in the water of $10.0 \%$ - from $7.24 \mu \mathrm{m} \cdot \mathrm{s}^{-1}$ (second 0 ) to $1.23 \mu \mathrm{m} \cdot \mathrm{s}^{-1}$ in the 30th second (Fig.1b). The mean VSL values obtained during 30 seconds differed significantly among spermatozoa activated in the water of $10.0 \%$ $\left(5.16 \mu \mathrm{m} \cdot \mathrm{s}^{-1}\right)$, those activated at 5.0\%o $\left(43.90 \mu \mathrm{m} \cdot \mathrm{s}^{-1}\right)$ and

Table 1

Ionic composition and $\mathrm{pH}$ of water used in experiments on sperm activity of brook trout, Salvelinus fontinalis

\begin{tabular}{cccccr}
\hline & \multicolumn{5}{c}{ Water salinity [\%o] } \\
\cline { 2 - 6 } Parameter & 0.35 & 1.0 & 3.0 & 5.0 & 10.0 \\
\hline $\mathrm{pH}$ & 7.7 & 7.3 & 8.2 & 8.4 & 8.5 \\
Sodium $\mathrm{Na}^{+}$ & 0.6016 & 17.0816 & 35.1968 & 78.2918 & 118.4379 \\
${\text { Magnesium } \mathrm{Mg}^{2+}}_{\text {Calcium } \mathrm{Ca}^{2+}}$ & 0.4168 & 1.0837 & 1.9165 & 5.0002 & 6.1930 \\
Potassium $\mathrm{K}^{+}$ & 1.5879 & 0.3396 & 0.7867 & 1.5263 & 2.2172 \\
${\text { Bromine } \mathrm{Br}^{-}}_{\text {Fluorine } \mathrm{F}^{-}}$ & 0.0479 & 0.2389 & 0.6799 & 1.5694 & 2.0346 \\
${\text { Chlorine } \mathrm{Cl}^{-}}$ & 0.0065 & 0.0017 & 0.0065 & 0.0177 & 0.0186 \\
& 0.0120 & 0.0043 & 0.0054 & 0.0517 & 0.0221 \\
\hline
\end{tabular}

Concentration of ions expressed in $\mathrm{mmol} \cdot \mathrm{dm}^{-3}$. 
those activated at $0.35 \%, 1.0 \%$, and $3.0 \%$ o $(22.68,25.89$, and $22.81 \mu \mathrm{m} \cdot \mathrm{s}^{-1}$, respectively) (Table 2 ).

Average-path sperm velocity (VAP). The highest VAP values were observed in second 0 among the spermatozoa activated in the culture water $(0.35 \%$ o $)$ and at $1.0 \%$ o $(83.92$ and $81.18 \mu \mathrm{m} \cdot \mathrm{s}^{-1}$, respectively). In the 5 th second of activation in the water of $5.0 \%$, as in the case of VCL and VSL, the mean VAP was very high, i.e., $89.70 \mu \mathrm{m} \cdot \mathrm{s}^{-1}$ (Fig. 1c). The lowest VAP values were recorded in the sample with spermatozoa activated in the water of $10.0 \% 0$ - they were within $17.88 \mu \mathrm{m} \cdot \mathrm{s}^{-1}$ (second 0 ) to $4.29 \mu \mathrm{m} \cdot \mathrm{s}^{-1}$ (30th second) (Fig.1c). The statistical analysis showed no significant differences in the mean values of VAP during 30 seconds among the samples activated at $0.35 \%$, $1.0 \%$, $3.0 \%$, and $5.0 \%$. Significant differences were demonstrated for the mean VAP of the spermatozoa activated at 10.0\%o (Table 2).

Amplitude of lateral head displacement (ALH). The highest ALH value, amounting to $0.76 \mu \mathrm{m}$, was recorded for the spermatozoa activated in the culture water in second 0 . With time the ALH decreased in all samples, to drop below $0.40 \mu \mathrm{m}$ in the 30th second. In the water of the highest salinity (10.0\%o), during 30 seconds the ALH was within a narrow range of $0.38-0.42 \mu \mathrm{m}$ (Fig 1d). Statistically significant differences in the ALH were observed between the spermatozoa activated at $10.0 \%$ and the remaining samples activated at $0.35 \%, 1.0 \%, 3.0 \%$, and 5.0\%o (Table 2).

Beat cross frequency BCF. The values of this parameter for the spermatozoa activated in the water of $0.35 \%$, $1.0 \%$, 3.0\%o, and $5.0 \%$ were within the range of $13.0 \mathrm{~Hz}$ (20th second at $0.35 \%$ ) to $2.8 \mathrm{~Hz}$ (20th second at $10.0 \%$ ) (Fig 1e). The mean BCF was the highest for the spermatozoa activated at $3.5 \%$ ( $(11.47 \mathrm{~Hz})$, and the lowest for those activated at $10.0 \%$ ( $6.40 \mathrm{~Hz})$ (Table 2$)$.

Linear motion (LIN). The highest LIN values were recorded in the 15 th second for the spermatozoa activated in the culture water $(0.35 \%$ ) $62.3 \%$. In that sample the LIN was observed to increase until the 15 th second, and then it decreased. However, the LIN value in the 30th second was $49.99 \%$ and was higher than immediately after activation $(35.10 \%)$. The LIN decreased with time in the case of the salinity water samples (Fig 1f.). The mean LIN (Fig. 1f) differed statistically significantly between the sample activated at $10.0 \%$ and the remaining samples activated in the water of lower salinity. The values of LIN in the samples of $0.35 \% \%_{0}-5.0 \%$ were within $38.75 \% \%^{-}-42.60 \%$, and at $10.0 \%$ the value was $24.07 \%$ (Table 2 ).

Motion straightness (STR). Like in the case of LIN, the values were the highest in the 15 th second, for the spermatozoa activated in the culture water $(0.35 \%$ o $-73.22 \%$. In that sample the STR increased till the 15 th second of activation, and then decreased. The lowest STR was recorded for the spermatozoa activated at $10.0 \%$ (Fig 1g). Like in the case of LIN, the mean STR differed statistically significantly between the sample activated at $10.0 \%$ and the remaining samples - salinities: $0.35 \%, 1.0 \%, 3.0 \%$, and 5.0\%o (Table 2).

Minimum and maximum value of sperm oscillation index (WOB). The parameter was the highest in the sample activated in the culture water $(0.35 \%)$ - in the 5 th second it was $86.87 \%$. In the remaining samples the WOB was lower and decreased with time to $38.26 \%$ in the 30 th second in the water of $10.0 \%$ (Fig. 1h). The mean WOB values were the highest in the sample of $0.35 \%$, and the lowest at $10.0 \%$. In the samples of $1.0 \%, 3.0 \%$, and $5.0 \%$ o they were similar (no statistically significant differences) (Table 2).

Percentage of motile spermatozoa (MOT) was the highest $(37.5 \%)$ in the sample activated in the culture water $(0.35 \%)$. In the remaining samples $(1.0 \%$, $3.0 \%$, $5.0 \%$, and $10.0 \%$ ) the MOT was within $19.2 \%(1.0 \%$ - $-9.1 \%$ (10.0\%) (Table 3). The MOT decreased with time, and in the $10.0 \%$ sample no motile spermatozoa were observed in the 35 th second.

Mean values of motility parameters of spermatozoa of brook trout, Salvelinus fontinalis,

Table 2 activated in water of different salinity

\begin{tabular}{|c|c|c|c|c|c|}
\hline \multirow{2}{*}{ Parameter } & \multicolumn{5}{|c|}{ Water salinity [\%o] } \\
\hline & 0.35 & 1.0 & 3.0 & 5.0 & 10.0 \\
\hline VCL & $60.68^{b}$ & $58.34^{\mathrm{b}}$ & $56.28^{b}$ & $69.21^{\mathrm{c}}$ & $19.09^{\mathrm{a}}$ \\
\hline VSL & $22.68^{\mathrm{b}}$ & $25.89^{b}$ & $22.80^{\mathrm{b}}$ & $43.90^{\mathrm{c}}$ & $5.16^{\mathrm{a}}$ \\
\hline VAP & $54.99^{\mathrm{b}}$ & $52.00^{\mathrm{b}}$ & $50.42^{\mathrm{b}}$ & $62.48^{\mathrm{c}}$ & $12.32^{\mathrm{a}}$ \\
\hline ALH & $0.57^{\mathrm{b}}$ & $0.55^{\mathrm{b}}$ & $0.53^{\mathrm{b}}$ & $0.54^{\mathrm{b}}$ & $0.40^{\mathrm{a}}$ \\
\hline $\mathrm{BCF}$ & $11.30^{\mathrm{c}}$ & $8.92^{\mathrm{b}}$ & $9.37^{\mathrm{bc}}$ & $10.32^{\mathrm{bc}}$ & $6.38^{\mathrm{a}}$ \\
\hline LIN & $41.93^{b}$ & $38.46^{\mathrm{b}}$ & $38.74^{\mathrm{b}}$ & $39.02^{\mathrm{b}}$ & $24.62^{\mathrm{a}}$ \\
\hline STR & $48.65^{\mathrm{b}}$ & $46.10^{\mathrm{b}}$ & $48.87^{\mathrm{b}}$ & $46.68^{b}$ & $38.41^{\mathrm{a}}$ \\
\hline WOB & $83.06^{\mathrm{c}}$ & $74.23^{\mathrm{b}}$ & $74.51^{\mathrm{b}}$ & $68.97^{\mathrm{b}}$ & $54.64^{\mathrm{a}}$ \\
\hline
\end{tabular}

The mean values of all measurement performed during 30 second; ANOVA $P<0.01$; mean values marked with identical superscripts are not significantly different at $P<0.01$, Duncan's multiple range test; $\mathrm{VCL}=$ curvilinear velocity $\left[\mu \mathrm{m} \cdot \mathrm{s}^{-1}\right]$, VSL $=$ straight-line velocity $\left[\mu \mathrm{m} \cdot \mathrm{s}^{-1}\right], \mathrm{VAP}=$ average-pathsperm velocity $\left[\mu \mathrm{m} \cdot \mathrm{s}^{-1}\right], \mathrm{ALH}=$ amplitude of lateral head displacement $[\mu \mathrm{m}], \mathrm{BCF}=$ beat cross frequency $[\mathrm{Hz}], \mathrm{LIN}=$ linear motion $[\%]\left(100 \mathrm{VSL} \cdot \mathrm{VCL}^{-1}\right), \mathrm{STR}=$ motion straightness $[\%]\left(100 \mathrm{VSL} \cdot \mathrm{VCL}^{-1}\right), \mathrm{WOB}=$ minimum and maximum value of sperm oscillation index [\%]. 

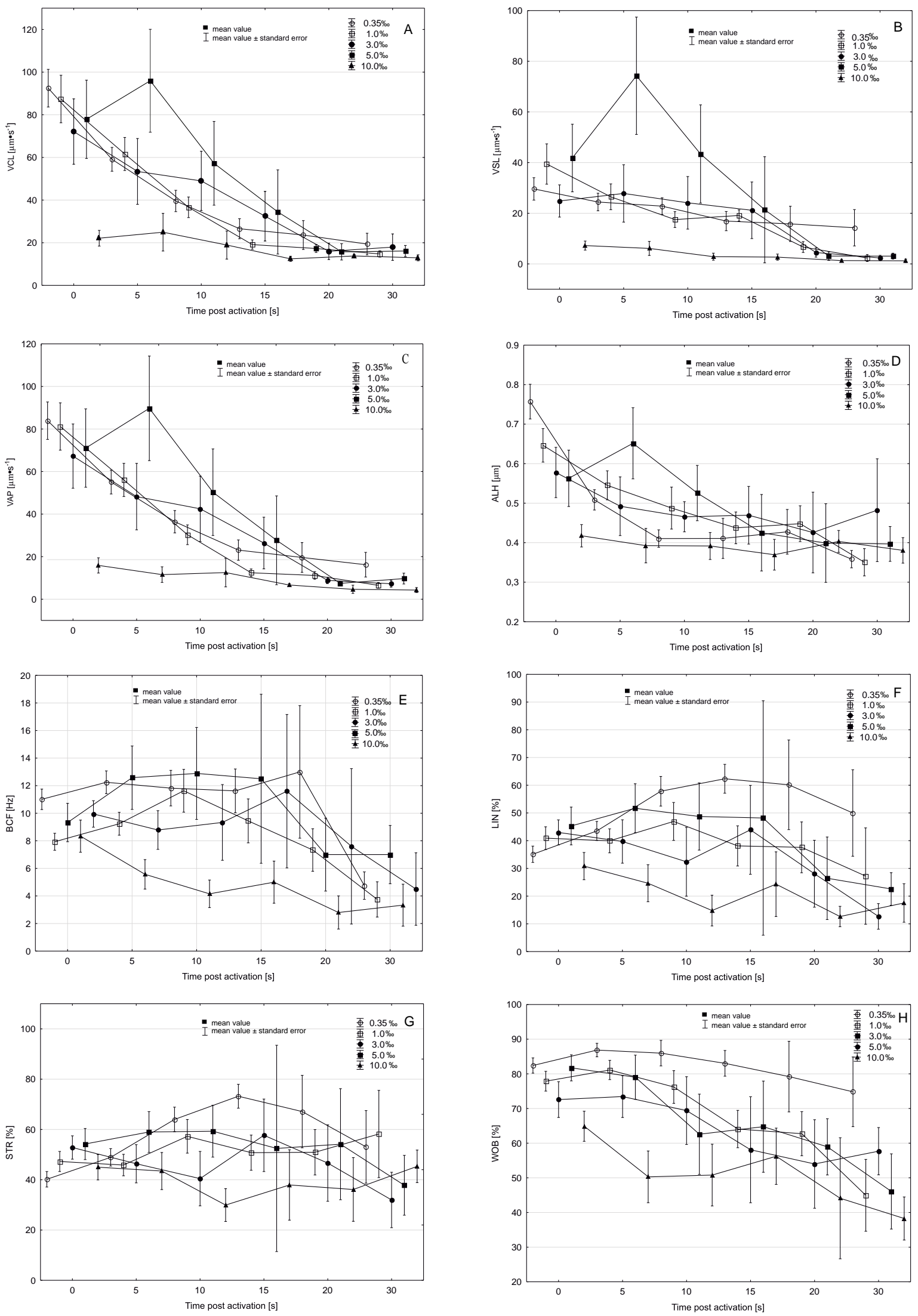

Fig. 1. Motility parameters of spermatozoa of brook trout, Salvelinus fontinalis, in different water-salinity treatments (0.35\%o, 1.0\%o, 3.0\%o, 5.0\%o, and 10.0\%o) analysed with CASA; A, curvilinear velocity (VCL); B, straight-line velocity (VSL); C, average-path sperm velocity (VAP); D, amplitude of lateral head displacement (ALH); E, beat cross frequency (BCF); F, linear motion (LIN); G, motion straightness (STR); H, minimum and maximum value of sperm oscillation index (WOB) 
Table 3

Percentage of motile spermatozoa (MOT) of brook trout, Salvelinus fontinalis, in different water-salinity treatments

\begin{tabular}{|c|c|c|c|c|c|}
\hline \multirow{2}{*}{ Time $[s]$} & \multicolumn{5}{|c|}{ Water salinity [\%o] } \\
\hline & 0.35 & 1.0 & 3.0 & 5.0 & 10.0 \\
\hline 0 & $37.5^{\mathrm{c}}$ & $19.2^{b}$ & $11.1^{\mathrm{a}}$ & $11.5^{\mathrm{a}}$ & $9.1^{\mathrm{a}}$ \\
\hline 5 & $17.8^{b}$ & $12.5^{b}$ & $8.9^{\mathrm{b}}$ & $12.1^{b}$ & $5.2^{\mathrm{a}}$ \\
\hline 10 & $10.4^{b}$ & $8.3^{\mathrm{b}}$ & $5.6^{\mathrm{a}}$ & $5.5^{\mathrm{a}}$ & $3.4^{\mathrm{a}}$ \\
\hline 15 & $9.3^{\mathrm{b}}$ & $6.3^{\mathrm{a}}$ & $5.0^{\mathrm{a}}$ & $5.8^{\mathrm{a}}$ & $3.9^{\mathrm{a}}$ \\
\hline 20 & $7.8^{\mathrm{b}}$ & $7.6^{\mathrm{b}}$ & $7.1^{\mathrm{ab}}$ & $4.6^{\mathrm{a}}$ & $3.6^{\mathrm{a}}$ \\
\hline 30 & $4.2^{\mathrm{b}}$ & $3.6^{\mathrm{ab}}$ & $4.2^{\mathrm{b}}$ & $4.7^{\mathrm{b}}$ & $2.0^{\mathrm{a}}$ \\
\hline
\end{tabular}

Mean values marked with identical superscripts are not significantly different at $P<0.01$; Duncan's multiple range test.

\section{DISCUSSION}

The results of the presently reported study indicate that the water of increased salinity, i.e., $1.0 \%$, 3.0\%o, 5.0\%o, and $10.0 \%$, used for activation affected the values of the studied motility parameters of brook trout spermatozoa. Our observations are compatible with the results of studies on rainbow trout and brown trout, indicating an increase in sperm motility in the water of increased mineralization (Szymelfenig 1979, Landergren and Vallin 1998). A higher salinity, of $14.0 \%-15.0 \%$, could probably completely immobilise brook trout spermatozoa, as was the case of spermatozoa of other species of the same family (Salmonidae), i.e., brown trout (Landergren and Vallin 1998). The spermatozoa of that species displayed their greatest motility in freshwater and the water of $6.7 \%$ (the highest values of linear and oscillating motion). In the water of $14.0 \%$, brown trout spermatozoa showed only oscillating movements, and at $16.0 \%$ and $18.0 \%$ no movement was observed (Landergren and Vallin 1998). The mean VCL of spermatozoa of the rainbow smelt - a fish of the family Osmeridae which is closely related to Salmonidae-at $15.0 \%$ and $20.0 \%$ was $50.0-150 \mu \mathrm{m} \cdot \mathrm{s}^{-1}$, but compared to the values observed at $0.0 \%$ o, $5.0 \%$, and $10.0 \%$ it was by ca. 50 percentage points smaller (Beirão et al. 2013).

The proportion of motile spermatozoa (MOT) immediately after activation at $10.0 \%$ was more than four times lower $(9.1 \%)$ than in the culture water $(37.5 \%)$ (Table 3 ). The studies by Dietrich et al. (2010) on the European whitefish spermatozoa showed that cations $\mathrm{Ca}^{2+}, \mathrm{K}^{+}$, and $\mathrm{Na}^{+}$decreased the percentage of motile spermatozoa, and the decrease was proportional to the cation concentration. Ions $\mathrm{Ca}^{2+}$ and $\mathrm{K}^{+}$at the concentration of $2.0 \mathrm{mmol} \cdot \mathrm{dm}^{-3}$ decreased MOT by ca. 10 percentage points in the case of calcium and ca. 35 percentage points in the case of potassium. The concentration of $\mathrm{Na}^{+}$of $120 \mathrm{mmol} \cdot \mathrm{dm}^{-3} \mathrm{de}-$ creased MOT by ca. 45 percentage points (Dietrich et al. 2010). In our studies the water of $10.0 \%$ had a similar content of cations: $2.22 \mathrm{mmol} \cdot \mathrm{dm}^{-3}$ (for $\mathrm{Ca}^{2+}$ ), $\mathrm{K}^{+} 2.03 \mathrm{mmol}$ $\cdot \mathrm{dm}^{-3}$ (for $\mathrm{K}^{+}$), and $118.44 \mathrm{mmol} \cdot \mathrm{dm}^{-3}$ (for $\mathrm{Na}^{+}$) (Table 1).

The viability and motility of fish spermatozoa depend on the adequate content of univalent $\left(\mathrm{K}^{+}, \mathrm{Na}^{+}\right)$and bivalent $\left(\mathrm{Ca}^{+2}, \mathrm{Mg}^{+2}\right)$ ions in the water, on the osmolality, and on $\mathrm{pH}$ (Morisawa et al. 1983, Cosson et al. 2000, Cosson 2004, Alavi and Cosson 2005). The prevalent ions in the fish seminal plasma are $\mathrm{Na}^{+}, \mathrm{K}^{+}, \mathrm{Cl}^{-}$, as well as $\mathrm{Ca}^{+2}$ and $\mathrm{Mg}^{+2}$. The ionic composition, however, may change during the spawning period; besides, the concentration of such ions as $\mathrm{Na}^{+}, \mathrm{K}^{+}$, and $\mathrm{Cl}^{-}$is higher in salmonids and cyprinids, and smaller in acipenserids (Alavi and Cosson 2006). Scheuring (1925) have already demonstrated that one of the factors initiating sperm movement in a salmonid (rainbow trout) was an adequate (smaller than in the seminal plasma) concentration of potassium ions $\left(\mathrm{K}^{+}\right)$in the water. Later studies showed that a solution of an elevated concentration of that ion amounting to $20-40 \mathrm{mmol} \mathrm{K}^{+}$, completely inhibited the motility of rainbow trout spermatozoa (Morisawa et al. 1983, Billard et al. 1986). However, diluting the semen with an isotonic solution of $\mathrm{NaCl}$ immediately restored motility (Billard et al. 1986, Gatti et al. 1990). Earlier studies demonstrated also that ions such as $\mathrm{Na}^{+}, \mathrm{Ca}^{+2}$, and $\mathrm{Mg}^{+2}$ at increased concentrations were antagonistic to $\mathrm{K}^{+}$ions (Scheuring 1925, Baynes et al. 1981) but were indispensable to initiate sperm motility (Christen et al. 1987, Cosson et al. 1989, Billard et al. 1995, Krasznai et al. 2000, Bondarenko et al. 2014)

In our studies on brook trout spermatozoa the concentration of ions in the water used for activation was diversified (Table 1$)$. The culture water $(0.35 \%)$ contained 0.048 $\mathrm{mmol} \cdot \mathrm{dm}^{-3}$ of $\mathrm{K}^{+}$, while the water of $10.0 \%$ contained over 42 times more of these ions $\left(2.035 \mathrm{mmol} \cdot \mathrm{dm}^{-3}\right)$. Also the concentration of the remaining ions increased with water salinity, and in case of $\mathrm{Na}^{+}$and $\mathrm{Cl}^{-}$their concentration in the water of $10.0 \%$, compared to the water of $0.35 \%$, was by $200-250$ percentage points higher (Table 1 ). The concentrations of ions in the seminal plasma of other salmonids, reported by other researchers, were as follows: 20.0-66.0 $\mathrm{mmol} \cdot \mathrm{dm}^{-3}$ (for $\mathrm{K}^{+}$), $103.0-140.0 \mathrm{mmol} \cdot \mathrm{dm}^{-3}$ $\left(\right.$ for $\mathrm{Na}^{+}$), 0.3-2.6 mmol $\cdot \mathrm{dm}^{-3}$ (for $\mathrm{Ca}^{+2}$ ), 130.0-135.0 $\mathrm{mmol} \cdot \mathrm{dm}^{-3}$ (for $\mathrm{Cl}^{-}$), 0.8-3.6 $\mathrm{mmol} \cdot \mathrm{dm}^{-3}$ (for $\mathrm{Mg}^{+2}$ ) (Billard et al. 1995, Lahnsteiner et al. 1998, Glogowski et al. 2000). It is therefore possible that the increased concentration of $\mathrm{K}^{+}, \mathrm{Na}^{+}$, and $\mathrm{Ca}^{+2}$ ions in the water of $10.0 \%$, though smaller than in the salmonid seminal plasma, does not have to be the reason for the decrease in the values of the studied sperm motility parameters. In case of $\mathrm{Mg}^{+2}$ $\left(6.193 \mathrm{mmol} \cdot \mathrm{dm}^{-3}\right)$ and $\mathrm{Cl}^{-}\left(145.073 \mathrm{mmol} \cdot \mathrm{dm}^{-3}\right)$ ions in the water of $10.0 \%$ the concentration is higher than that in the salmonid seminal plasma which may affect the motility parameters which were very low in that sample. It should be noted, however, that ion concentrations in the 
seminal plasma varies among salmonid species. The content of $\mathrm{K}^{+}$in rainbow trout plasma was within 25.3-30.4 $\mathrm{mmol} \cdot \mathrm{dm}^{-3}$ (Glogowski et al. 2000) and in chum salmon it was $66.1 \mathrm{mmol} \cdot \mathrm{dm}^{-3}$ (Morisawa and Suzuki 1980). The content of $\mathrm{Ca}^{+2}$ in rainbow trout plasma was within 1.1-2.2 $\mathrm{mmol} \cdot \mathrm{dm}^{-3}$ (Glogowski et al. 2000), in chum salmon it is $2.2 \mathrm{mmol} \cdot \mathrm{dm}^{-3}$ (Morisawa and Suzuki 1980, Lahnsteiner et al. 1998, Glogowski et al. 2000).

No information is available on the content of the studied ions in brook trout seminal plasma. However, based on the results of studies on other salmonid species it can be suspected that a too high content of such ions in the activation water of $10.0 \%$ may be a factor inhibiting the movement of spermatozoa of that species.

Another factor which may affect the motility of brook trout spermatozoa is pH. Ciereszko et al. (2010) observed the highest values of sperm motility (\%) in brook trout at $\mathrm{pH}$ of 8.0-9.0. The solutions used in our experiments had only slightly different $\mathrm{pH}$ which increased with increasing salinity (Table 1) and was within 7.68-8.52. Considering the results of Ciereszko et al. (2010) it was the range in which sperm motility should be as high as $85 \%-90 \%$. In our studies the MOT for freshwater was more than twice lower, reaching 37.5\%. Such low values of the sperm motility parameters may be associated with the use of culture water for activation of control sample $(0.35 \%)$, and salinity water, as well as the duration of transport of the material to the laboratory $(1.5 \mathrm{~h})$, and the semen sampling method-without catheter (Glogowski et al. 2000). This is confirmed by the studies in which $\mathrm{NaCl}$ and sucrose solution of varied osmolality $(0,100$, and $300 \mathrm{mOsm} \cdot \mathrm{kg}^{-1}$ ) was used for activation of control sample of brook trout spermatozoa; the sperm motility was high and exceeded $70.0 \%$. When activating liquids were used, the MOT increased to more than $90.0 \%$ (Bondarenko et al. 2014).

It can be concluded from our results that the water of $1.0 \%$ and $3.0 \%$ salinity, used for activation of brook trout spermatozoa, caused a decrease in the values of the studied motility parameters, while in the water of $5.0 \%$ salinity the values increased and were higher than in control sample $(0.35 \%$ ). Activation of spermatozoa in the water of the highest salinity $(10.0 \%)$ caused a distinct decrease in the values of all studied parameters which may have resulted from too high ion concentration in the water.

Salmonid spermatozoa are characterised by a very short time of activity in the water, hence sudden water pollution in the form of increased salinity on the spawning grounds may have a negative effect on the sperm motility parameters, thus affecting the subsequent egg fertilisation and, consequently the number of the hatched individuals of the species.

\section{ACKNOWLEDGEMENTS}

We are very grateful to Dr Sylwia Machula who analysed the ionic composition of the water used in the experiments.

\section{REFERENCES}

Alavi S.M.H., Cosson J. 2005. Sperm motility in fishes. I. Effects of temperature and $\mathrm{pH}$ : A review. Cell Biology International 29 (2): 101-110.

DOI: 10.1016/j.cellbi.2004.11.021

Alavi S.M.H., Cosson J. 2006. Sperm motility in fishes. (II) Effects of ions and osmolality: A review. Cell Biology International 30 (1): 1-14.

DOI: $10.1016 /$ j.cellbi.2005.06.004

Alavi S.M.H., Linhart O., Coward K., Rodina M. 2008. Fish spermatology: implications for aquaculture management. Pp. 397-460. In: Alavi S.M.H. Cosson J., Coward K., Rafiee G. (eds.) Fish spermatology. Alpha Science International, Oxford, UK.

Baynes S.M., Scott A.P., Dawson A.P. 1981. Rainbow trout, Salmo gairdnerii Richardson, spermatozoa: Effect of cations and $\mathrm{pH}$ on motility. Journal of Fish Biology 19 (3): 259-267.

DOI: $10.1111 /$ j.1095-8649.1981.tb05830.x

Beirão J., Lewis J., Purchase C.F. 2013. Semen biology and the effects of salinity on sperm activation in two osmerids that spawn in different environments. 4th International Workshop on the Biology of Fish Gametes. 17-20 September 2013, Albufeira, Portugal. The Fourth International Workshop on the Biology of Fish Gametes, Albufeira, Algarve

Beirão J., Lewis J., Purchase C.F. 2015a. Spermatozoa ultrastructure of two osmerid fishes in the context of their family (Teleostei: Osmeriformes: Osmeridae). Journal of Applied Ichthyology 31 (Suppl. 1): 28-33. DOI: $10.1111 /$ jai.12724

Beirão J., Purchase C.F., Wringe B.F., Fleming I.A. 2015b. Inter-population ovarian fluid variation differentially modulates sperm motility in Atlantic cod $G a-$ dus morhua. Journal of Fish Biology

DOI: $10.1111 / \mathrm{jfb} .12685$

Billard R. 1978. Changes in structure and fertilizing ability of marine and freshwater fish spermatozoa diluted in media of various salinities. Aquaculture 14 (3): 187-198.

DOI: $10.1016 / 0044-8486(78) 90094-7$

Billard R. 1986. Spermatogenesis and spermatology of some teleost fish species. Reproduction Nutrition Development 26 (4): 877-920.

DOI: $10.1051 / \mathrm{rnd}: 19860601$

Billard R., Christen R., Cosson M.P., Gatty J.L., Letellier L., Renard P., Saad A. 1986. Biology of the gametes of some teleost species. Fish Physiology and Biochemistry 2 (1-4): 115-20.

DOI: $10.1007 / \mathrm{BF} 02264079$

Billard R., Cosson J., Crim L.W., Suquet M. 1995. Sperm physiology and quality. In: Bromage N.R., Roberts R.J. (eds.) Brood stock management and egg and larval quality. Blackwell Science, Oxford, UK.

Bondarenko O., Dzyuba B., Cosson J., Rodina M., Linhart O. 2014. The role of $\mathrm{Ca}^{2+}$ and $\mathrm{Na}^{+}$membrane transport in brook trout (Salvelinus fontinalis) sperma- 
tozoa motility. Fish Physiology and Biochemistry 40 (5): 1417-1421.

DOI: $10.1007 / \mathrm{s} 10695-014-9936-5$

Bonisławska M. 2009. Effects of salinity on the duration and course of embryogenesis in sea trout (Salmo trutta L.). Electronic Journal of Polish Agricultural Universities 12 (4). http://www.ejpau.media.pl/volume12/ issue 4/art-07.htlm

Burness G., Moyes C.D., Montgomerie R. 2005. Motility, ATP levels and metabolic enzyme activity of sperm from bluegill (Lepomis macrochirus). Comparative Biochemistry and Physiology Part A: Molecular and Integrative Physiology 140 (1): 11-17.

DOI: 10.1016/j.cbpb.2004.09.021

Christen R., Gatti J.L., Billard R. 1987. Trout sperm motility: The transient movement of trout sperm is related to changes in the concentration of the ATP following the activation of the flagellar movement. European Journal of Biochemistry 166 (3): 667-671. DOI: $10.1111 /$ j.1432-1033.1987.tb13565.x

Ciereszko A. 2008. Chemical composition of seminal plasma and its physiological relationship with sperm motility, fertilizing capacity and cryopreservation success in fish. In: Alavi S.M.H., Cosson J., Howard K., Rafiee G. (eds.) Fish spermatology. Alfa Science International, Oxford, UK.

Ciereszko A., Dietrich G.J., Dietrich M.A., Nynca J., Kuźmiński H., Dobosz S., Grudniewska J. 2010. Effect of $\mathrm{pH}$ on sperm motility in several Salmoniformes species: Oncorhynchus mykiss, Salvelinus fontinalis, Salmo trutta, Salmo salar and Thymallus thymallus. Journal of Applied Ichthyology 26 (5): 665-667. DOI: $10.1111 / \mathrm{j} .1439-0426.2010 .01536 . x$

Cosson J. 2004. The ionic and osmotic factors controlling motility of fish spermatozoa. Aquaculture International 12 (1): 69-85.

DOI: 10.1023/B:AQUI.0000017189.44263.bc

Cosson J., Billard R., Cibert C., Dreanno C., Suquet M. 1999. Ionic factors regulating the motility of fish sperm. Pp. 161-186. In: Gagnon. C (eds.) The male gamete: From basic science to clinical applications. Cache River Press. Vienna, IL, USA.

Cosson J., Linhart O., Mims S., Shelton W., Rodina M. 2000. Analysis of motility parameters from paddlefish and shovelnose sturgeon spermatozoa. Journal of Fish Biology 56 (6): 1348-1367. DOI: 10.1111/j.1095-8649.2000.tb02148.x

Cosson M.P., Billard R., Letellier L. 1989. Rise of internal $\mathrm{Ca}^{2+}$ accompanies the initiation of trout sperm motility. Cell Motility and the Cytoskeleton 14 (3): 424-434.

DOI: $10.1002 / \mathrm{cm} .970140312$

Dietrich G.J., Dietrich M., Hliwa P., Stabinski R., Nynca J., Andronowska A., Ciereszko A. 2010. Semen biology of vendace (Coregonus albula L.). Fish Physiology and Biochemistry 36 (3): 419-425.

DOI: $10.1007 / \mathrm{s} 10695-009-9311-0$

Dziekońska J. 1958. Badania nad wczesnymi stadiami rozwojowymi ryb. II. Wpływ niektórych warunków środowiska na rozwój embrionalny leszcza (Abramis brama (L.)) w Zalewie Wiślanym. [Studies on early development stages of fish. II. The influence of some environment conditions on the embryonic development of bream (Abramis brama (L.)) in the Vistula Lagoon]. Polish Archives of Hydrobiology 4: 194-206. [In Polish with English summary.]

Fashina-Bombata H.A., Busari A.N. 2003. Influence of salinity on the developmental stages of African catfish Heterobranchus longifilis (Valenciennes, 1840). Aquaculture 224 (1-4): 213-222.

DOI: $10.1016 / \mathrm{S} 0044-8486(03) 00273-4$

Fopp-Bayat D., Jankun M., Kuźmiński H. 2010. Genetic characterization of Polish cultured brook trout, Salvelinus fontinalis (Mitchill), based on microsatellite DNA analysis. Archives of Polish Fisheries 18 (2): 93-99.

DOI: $10.2478 / \mathrm{v} 10086-010-0011-2$

Formicki K., Szulc J., Tański A., Korzelecka-Orkisz A., Witkowski A., Kwiatkowski P. 2013. The effect of static magnetic field on Danube huchen. Hucho hucho (L.) sperm motility parameters. Archives of Polish Fisheries 21 (3): 189-197.

DOI: $10.2478 /$ aopf-2013-0016

Fridman S., Bron J., Rana K. 2012. Influence of salinity on embryogenesis, survival, growth and oxygen consumption in embryos and yolk-sac larvae of the Nile tilapia. Aquaculture 334-337: 192-190.

DOI: $10.1016 /$ j.aquaculture.2011.12.034

Gage M.J.G., Macfarlane C.P., Yeates S., Ward R.G., Searle J.B., Parker G.A. 2004. Spermatozoal traits and sperm competition in Atlantic salmon: Relative sperm velocity is the primary determinant of fertilization success. Current Biology 14 (1): 44-47. DOI: 10.1016/S0960-9822(03)00939-4

Gatti J.L., Billard R., Christen R. 1990. Ionic regulation of the plasma membrane potential of rainbow trout (Salmo gairdneri ) spermatozoa: Role in the initiation of sperm motility. Journal of Cellular Physiology 143 (3): $546-564$.

DOI: $10.1002 /$ jcp. 1041430320

Glogowski J., Kwaśnik M., Piros B., Dąbrowski K., Goryczko K., Dobosz S., Kuźminski H., Ciereszko A. 2000. Characterization of rainbow trout milt collected with a catheter: Semen parameters and cryopreservation success. Aquaculture Research 31 (3): 289-296. DOI: 10.1046/j.1365-2109.2000.00400.x

Inaba K., Dréanno C., Cosson J. 2003. Control of flatfish sperm motility by $\mathrm{CO}_{2}$ and carbonic anhydrase. Cell Motility and the Cytoskeleton 55 (3): 174-187. DOI: $10.1002 / \mathrm{cm} .10119$

Ivlev V.S. 1940. Vliânie solenosti na oplodotvorenie i razvitie ikry niekotoryh kaspijskich poluprohodnyh ryb. [The influence of the salinity on fertilization and development of the eggs of some Caspian semi-migratory fish.] Zoologičeskij Žurnal 19 (3): 471-477.

Janson E., Gzyl G., Banks D. 2009. The occurrence and quality of mine water in the Upper Silesian coal ba- 
sin, Poland. Mine Water and the Environment 28 (3): 232-244.

DOI: 10.1007/s10230-009-0079-3

Khatooni M.M., Amiri B.M., Mirvaghefi A., Jafari V., Hoseinifar S.H. 2012. The effects of salinity on the fertilization rate and rearing of the Persian sturgeon (Acipenser persicus) larvae. Aquaculture International 20 (6): 1097-1105.

DOI: $10.1007 / \mathrm{s} 10499-012-9560-2$

Krasznai Z., Márián T., Izumi H., Damjanovich S., Balkay L., Trón L., Morisawa M. 2000. Membrane hyperpolarization removes inactivation of $\mathrm{Ca}^{2+}$ channels, leading to $\mathrm{Ca}^{2+}$ influx and subsequent initiation of sperm motility in the common carp. Proceedings of the National Academy of Sciences of the United States of America 97 (5): 2052-2057.

DOI: $10.1073 /$ pnas.040558097

Krasznai Z., Morisawa M., Morisawa S., Krasznai Z.T., Trón L., Gáspár R., Márián T. 2003. Role of ion channels and membrane potential in the initiation of carp sperm motility. Aquatic Living Resources 16 (5): 445-449.

DOI: $10.1016 / \mathrm{S} 0990-7440(03) 00054-8$

Landergren P., Vallin L. 1998. Spawning of sea trout, Salmo trutta L., in brackish waters-lost effort or successful strategy? Fisheries Research 35 (3): 229-236. DOI: 10.1016/S0165-7836(98)00073-3

Lahnsteiner F., Berger B., Weismann T., Patzner R.A. 1998. Determination of semen quality of the rainbow trout, Oncorhynchus mykiss, by sperm motility, seminal plasma parameters, and spermatozoal metabolism. Aquaculture 163 (1-2): 163-181.

DOI: $10.1016 / \mathrm{S} 0044-8486(98) 00243-9$

Lindroth A. 1946. Zur Biologie der Befruchtung und Entwicklung beim Hecht. Gäddans befruktnings - och utvecklingsbiologi samt gäddkläckning i glas. Meddelanden från Statens undersöknings- och försöksanstalt för sötvattensfisket No. 24.

Morisawa M., Suzuki K. 1980. Osmolality and potassium ion: Their roles in initiation of sperm motility in teleosts. Science 210 (4474): 1145-1147.

DOI: $10.1126 /$ science. 7444445
Morisawa M., Suzuki K., Shimizu H., Morisawa S., Yasuda K. 1983. Effect of osmolality and potassium on motility of spermatozoa from freshwater cyprinid fishes. Journal of Experimental Biology 107 (1): 95-103.

Scheuring L. 1925. Biologische und physiologische Untersuchungen an Forellensperma. Archiv für Hydrobiologie Supplement 4: 181-318.

Shimoda E., de Andrade D.R., Vidal Júnior M.V., Yasui G.S., Silva J.F.S., Godinho H.P., Souza G. 2007. Efeitos da osmolaridade sobre a motilidade espermática na piabanha Brycon insignis. [Effects of osmolarity on sperm motility of tiete tetra, Brycon insignis.] Revista Ceres 54 (315): 430-433. [In Portuguese.]

Stoss J. 1983. Fish gamete preservation and spermatozoan physiology. Pp. 305-350. In: Hoar W.S., Randal D.J., Donaldson E.M. (eds.) Fish physiology. Vol. 9. Reproduction, Part B. Behavior and fertility control. Academic Press, London.

Swanson C. 1996. Early development of milkfish: Effects of salinity on embryonic and larval metabolism, yolk absorption and growth. Journal of Fish Biology 48 (3): 405-421. DOI: $10.1111 / \mathrm{j} .1095-8649.1996 . t b 01436 . x$

Szymańska H. 1990. Wpływ słonych wód z kopalń węgla kamiennego na jakość wód Odry. [The effect of saline waters from coal mines on the quality of waters of the Oder River.] Gospodarka Wodna 5: 116-122. [In Polish.]

Szymelfenig M. 1979. Wpływ wody morskiej o różnych zasoleniach na pleminki i jaja pstrąga tęczowego (Salmo gairdneri Rich 1836) i troci wędrownej (Salmo gairdneri Rich 1836). [The effect of sea water of varying salinity on the eggs and sperm of rainbow trout (Salmo gairdneri Rich 1836) and brown trout (Salmo trutta trutta L. 1758).] Zeszyty Naukowe Wydziału Biologii i Nauk o Ziemi Uniwersytetu Gdańskiego, Oceanografia 6 (9): 129-146. [In Polish with English summary.]

Vetemaa M., Saat T. 1996. Effects of salinity on the development of fresh-water and brackish-water ruffe Gymnocephalus cernuus (L.) embryos. Annales Zoologici Fennici. 33 (3-4): 687-691.

Received: 25 September 2014 Accepted: 24 February 2015 Published electronically: 30 June 2015 